\title{
HUBUNGAN POLA ASUH ORANG TUA DENGAN KEMATANGAN EMOSI REMAJA DI SMA N 1 SINONSAYANG
}

\author{
Nikita Lumenta \\ Herlina I. S. Wungouw \\ Michael Karundeng \\ Program Studi Ilmu Keperawatan Fakultas Kedokteran \\ Univeristas Sam Ratulangi \\ Email:nikitalumenta76@gmail.com
}

\begin{abstract}
Abstrack Emotional maturity is a person's ability to control and control his emotions well. This is based on a condition of feeling or reaction feeling stable towards an object of the problem so that to take a decision or behavior based on a consideration. One of the factors that influence emotional maturity is parenting which is divided into three types, namely authoritarian parenting, permissive parenting, and democratic parenting. The purpose of this study was to determine the relationship of parenting parents with the emotional maturity of adolescents in SMA N 1 Sinonsayang. The design method uses a cross sectional approach. Respondents consisted of 95 teenagers with sampling techniques using total sampling. Data collection using a questionnaire. Chi Square Test Results with a confidence level of $95 \% v(\alpha$ $0.05)$, where the value of $p=0,018$ is smaller than $\alpha=0.05$. The conclusion is there is a relationship between parenting parents and adolescent emotional maturity in SMA $\mathrm{N} 1$ Sinonsayang
\end{abstract}

Keywords: Parenting patterns, emotional maturity, adolescence

\begin{abstract}
Abstrak Kematangan emosi adalah kemampuan seseorang dalam mengontrol dan mengendalikan emosinya secara baik. Hal ini didasari sebagai suatu kondisi perasaan atau reaksi perasaan yang stabil terhadap suatu objek permasalahan sehingga untuk mengambil suatu keputusan atau tingkah laku didasari dengan suatu pertimbangan. Salah satu faktor yang mempengaruhi kematangan emosi adalah pola asuh orang tua yang terbagi dalam tiga tipe, yaitu pola asuh otoriter, pola asuh permisif, dan pola asuh demokratis. Tujuan penelitian ini adalah mengetahui hubungan pola asuh orang tua dengan kematangan emosi remaja di SMA N 1 Sinonsayang. Metode penelitian menggunakan pendekatan cross sectional. Responden terdiri dari 95 remaja dengan teknik pengambilan sampel menggunakan Total Sampling. Pengumpulan data menggunakan kuesioner. Hasil Uji Chi Square dengan tingkat kepercayaan $95 \% \mathrm{v}(\alpha 0,05)$, dimana nilai $\mathrm{p}=0,018$ lebih kecil dari $\alpha=0,05$. Kesimpulan ada hubungan antara pola asuh orang tua dengan kematangan emosi remaja di SMA $\mathrm{N} 1$ Sinonsayang.
\end{abstract}

Kata Kunci: Pola asuh orang tua, Kematangan emosi, Remaja. 


\section{PENDAHULUAN}

Remaja yang dalam bahasa latin disebut adolescence yang berarti "tumbuh" atau "tumbuh menjadi dewasa". Istilah remaja mempunyai arti yang lebih luas mencakup kematangan emosional, mental, sosial dan fisik, dimana masa remaja merupakan masa transisi dalam rentang kehidupan manusia yang menghubungkan masa kanak-kanak dan masa dewasa (Ali \& Asrori, 2010). Menurut WHO remaja merupakan penduduk dalam rentang usia 10-19 tahun, menurut Menteri Kesehatan RI Nomor 25 tahun 2014, remaja merupakan penduduk dalam rentang usia 10-18 tahun dan menurut Badan Kependudukan Keluarga Berencana (BKKBN) rentang usia remaja 10-24 tahun dan belum menikah. Jumlah kelompok usia 10-19 tahun di Indonesia menurut sensus penduduk 2010 sebanyak 43,5 juta atau sekitar $18 \%$ dari jumlah penduduk. Jumlah remaja di dunia diperkirakan berjumlah 1,2 milyar atau $18 \%$ dari jumlah penduduk dunia (Kementrian Kesehatan RI, 2014). Seorang remaja dikatakan telah memiliki kematangan emosi bila ia memiliki karakteristik seperti mudah mengalirkan cinta dan kasih sayang, mampu untuk menghadapi kenyataan, kemampuan menilai secara positif pengalaman hidup, mampu berfikir positif mengenai diri pribadi, penuh harapan, ketertarikan untuk memberi, kemampuan untuk belajar dari pengalaman, kemampuan menangani permusuhan konstruktif, berfikir terbuka (Kapri \& Rani, 2014).

Kematangan emosi adalah kesadaran yang mendalam terhadap kebutuhankebutuhan, keinginan-keinginan, cita-cita, alam perasaannya serta pengintegrasian sehingga mampu memberikan reaksi emosional yang stabil, tidak berubah-ubah dari satu suasana hati ke suasana hati yang lain dan mampu menekan/mengontrol emosi yang timbul secara baik walaupun pada situasi yang kurang menyenangkan. Kematangan emosi sangat mempengaruhi pola perilaku remaja, karena kematangan emosi menyebabkan remaja berperilaku realistis dan tidak gegabah dalam mengambil keputusan (Astuti, 2012). Pembentukan kematangan emosi tidak lepas dari peranan pola asuh orangtua, karena orangtua adalah orang pertama yang memiliki peranan dalam mengatur dan mendidik seorang remaja untuk memperoleh kematangan emosi yang baik (Hurlock 2004). Pola asuh sebagai pola sikap atau perlakuan orangtua terhadap remaja yang masing-masing mempunyai pengaruh tersendiri terhadap perilaku remaja antara lain terhadap kompetensi emosional, sosial, dan intelektual. Terdapat tiga pola asuh orangtua terhadap remaja dimana masing-masing memiliki kontribusi yang penting dalam pembentukan karakter anak. Pola asuh tersebut yaitu authoritative, authoritarian dan permissive. (Baumrind, 2012).

Penelitian yang dilakukan Yuni (2018) yaitu untuk mengetahui apakah ada hubungan pola asuh orang tua dengan kematangan emosi remaja dan dalam peneitian ini terdapat hasil yang signifikan antara pola asuh orang tua dengan kematangan emosi remaja dan dalam penelitian ini digunakan metode kuantitatif korelasional, adapun pendekatan yang dilakukan adalah kuantitatif. Dari pendataan awal yang penulis peroleh di SMA N 1 Sinonsayang jumlah siswa keseluruhan terdapat 125 siswa terdiri dari 73 siswa perempuan dan siswa laki-laki berjumlah 52. Dari wawancara pada pihak sekolah terdapat gambaran mengenai kematangan emosi siswa yaitu menunjukkan bahwa siswa kurang bisa dalam mengendalikan emosinya, misalnya seperti ada siswa yang melampiasakan kemarahannya dengan teman dekatnya, bertengkar, saling merendahkan sesama temanya, suka berkata kasar, dan merokok di lingkungan sekolah. Di lihat dari pendataan awal diharapkan siswa mampu mengendalikan emosinya dan mampu berpikir secara baik sehingga dalam belajar akan memperoleh hasil yang baik pula. Berdasarkan uraian di atas maka peneliti tertarik untuk melakukan penelitian 
tentang adanya hubungan pola asuh orang tua dengan kematangan emosi remaja di SMA N 1 Sinonsayang.

\section{METODE PENELITIAN}

Desain penelitian ini adalah cross sectional yaitu Variabel independen dan Variabel dependen akan dilakukan serta dikumpulkan secara bersamaan (Setiadi, 2013). Penelitian ini dilaksanakan di SMA N 1 Sinonsayang dalam waktu 1 bulan yaitu bulan Maret 2019. Populasi dalam penelitin ini adalah seluruh siswa di SMA $\mathrm{N} 1$ Sinonsayang. Penentuan jumlah sampel pada penelitian ini dilakukan perhitungan menggunakan rumus Slovin. Setiadi (2013) dan didapati hasil 95 responden yang memenuhi kriteria inklusi yaitu: siswa yanag bersedia menjadi responden, siswa yang hadir saat pengambilan data. Kriteria eksklusi: siswa yang tidak hadir saat pengambilan data, siswa yang tidak mengisi kuesioner, siswa yang tidak tinggal serumah dengan orang tua kandung (ayah dan ibu). Penelitian ini menggunakan instrumen berupa kuesioner dan kuesioner ini sudah pernah di teliti oleh Cici Devi (2012). Kuesioner pola asuh terdiri dari 48 pertanyaan dimana pola asuh Baik dengan skor $\leq 120$, pola asuh yang kurang baik $\geq 120$ kuesioner kematangan emosi terdiri dari 30 pertanyaan dan kuesioner ini sudah pernah diteliti oleh Yahya (2012) pertanyaan dibagi dalam dua kategori terkontrol dan tidak terkontrol jika skor $>75$ terkontrol jika skor $<=75$ tidak terkontrol. Penelitian ini menggunakan Data primer adalah data yang diperoleh langsung dari responden dan data sekunder data yang diperoleh dari dari rekaptulisasi jumlah siswa di SMA N 1 Sinonsayang.

Pengolahan data pada penelitian ini menggunakan pengolahan data dari Notoatmojo (2012) diperoleh dari hasil secara manual dengan mengelompokan hasil dari lembar kuesioner yang dibagikan dan selanjutnya dilakukan analisis menggunakan uji statistik. Setelah itu diolah menggunakan system komputerisasi, tahap-tahap tersebut yaitu editing, coding, tabulating, dan analisa univariat dilakukan untuk menganalisa variabel pola asuh orang tua dan variabel kematangan emosi. Analisa bivariat yang digunakan adalah hasil tabulasi silang. Untuk menguji hipotesa dilakukan analisa kemaknaan 95\% (P.Value < 0, 05). Setelah diuji hasil memenuhi syarat dan di Tarik suatu kesimpulan dimana nilai $p$-value $<0$, 05). Maka sesuai dengan Hipotesis awal bahwa ada hubungan antara variabel dependen dan variabel independen.

\section{HASIL dan PEMBAHASAN}

\section{Analisa Univariat}

Tabel 1. Distribusi Responden Menurut Pola Asuh Orang Tua

\begin{tabular}{ccc}
\hline $\begin{array}{c}\text { Pola asuh orang } \\
\text { tua }\end{array}$ & $\mathbf{n}$ & $\boldsymbol{\%}$ \\
\hline Baik & 50 & 52,6 \\
Kurang Baik & 45 & 47,4 \\
\hline Total & $\mathbf{9 5}$ & $\mathbf{1 0 0 \%}$ \\
\hline
\end{tabular}

Sumber: data primer, 2019

Sebagian besar responden mendapatkan pola asuh orang tua yang baik yaitu sebanyak $50(52,6 \%)$. Dilihat juga dari penelitian yang dilakukan, terdapat responden yang telah mendapatkan pola asuh yang baik seperti mengahargai penulis dalam melakukan penelitian, sopan dalam berkomunikasi dan mengisi kuesioner dengan baik. Peneliti juga berasumsi bahwa pola asuh orangtua yang diterapkan di rumah pada responden kebanyakan responden sudah mendapatkan pola asuh yang baik dari orang tua.

Menurut Wong (2009) pola pengasuhan merupakan suatu proses mendidik, membimbing, dan mendisiplinkan serta melindungi anak untuk mencapai kedewasaan sesuai dengan norma dalam masyarakat, pola asuh dibagi menjadi tiga tipe yaitu otoriter, demokratis, dan permisif. Menurut Petranto (Suarsini, 2013) pola asuh orang tua merupakan pola perilaku yang diterapkan pada anak bersifat relative, konsisten dari waktu ke 
waktu. Pola perilku ini dirasakan oleh anak, dari segi negative maupun positif. Pola asuh yang diterapakan tiap keluarga berbeda, hal ini tergantung pandangan dari tiap orang tua. Pola asuh orang tua adalah salah satu faktor yang mempengaruhi kematangan emosi remaja karena dalam pengalamannya berinteraksi dengan keluarga akan menentukan pola-pola perilaku anak terhadap orang lain dalam lingkungannya serta cara-cara orang tua dalam memperlakukan anak-anaknya akan memberikan akibat yang permanen dalam kehidupan anak.

Pola asuh orang tua memilki
pengaruh yang sangat besar bagi keperibadian anak yang tungguh sehingga anak berkembang menjadi pribadi yang percaya diri, berinisiatif, berambisi, beremosi stabil bertanggung jawab, dan mampu menjalin hubungan interpersonal yang posifit. Pola asuh orang tua juga berpengaruh bagi kematangan emosi remaja. Orang tua merupakan lembaga pertama dan utama dalam kehidupan anak, tempat belajar dan menyatakan diri sebagai makhluk sosial. Karena keluarga merupakan kelompok social yang pertama termpat anak dapat berinterksi. Dari pengalamannya berinteraksi di dalam keluarga ini akan menentukan pola perilaku anak terhadap orang lain di dalam lingkungannya. Pola asuh orang tua adalah salah satu faktor yang mempengaruhi kematangan emosi remaja. Karena keluarga sebagai pengasuh dan pembimbing dalam meletakkan dasardasar perilaku remaja karena sikap, perilaku dan kebisan orang tua selalu dilihat, dinilai dan ditiru oleh anaknya yang kemudian semua itu secara sadar atau tidak sadar diresapinya dan kemudian menjadi kebiasaan pula bagi anaknya. Sejalan dengan penelitian dari Ferieska (2016) terdapat hubungan yang signifikan antara pola asuh orang tua dengan kematangan emosi remaja. Pola asuh orang tua merupakan pola asuh yang dapat menimbulkan sikap kematangan emosi pada remaja dengan demikian dapat dikatakan bahwa pola asuh yang diterapkan orangtua di rumah akan berdampak kepada perilaku yang ditimbulkan remaja. Kondisi ini akan mendorong tumbuh dan berkembangnya aspek kematangan emosi remaja. Namun penelitian ini tidak sejalan dengan penelitian yang dilakukan oleh Purwanti (2013) dimana dalam penelitian ini mengatakan tidak ada hubungan antara pola asuh dengan kematangan emosi.

Tabel 2. Distribusi Responden Berdasarkan Kematangan Emosi Remaja

\begin{tabular}{lcc}
\hline $\begin{array}{c}\text { Kematangan } \\
\text { emosi }\end{array}$ & n & \% \\
\hline Terkontrol & 47 & 49,5 \\
Tidak & 48 & 50,5 \\
terkontrol & & \\
\hline \multicolumn{1}{c}{ Total } & $\mathbf{9 5}$ & $\mathbf{1 0 0 \%}$ \\
\hline
\end{tabular}

Sumber: data primer, 2019

Penelitian tentang kematangan emosi yang telah dilakukan didapatkan bahwa sebagian besar responden sudah memiliki kematangan emosi yang tidak terkontrol sebanyak 50, 5 (48 orang) dan sisanya terkontrol sebanyak 49,5 (47 orang). Penelitian dapat dilihat melalui gejalagejala dalam bentuk tingkah laku, respon maupun sikap remaja dalam berinteraksi terhadap lingkungan sekitarnya. Istilah kematangan emosi sering kali membawa implikasi adanya kontrol emosi. Dari kematangan emosi ini, maka para siswa di harapkan untuk menjadi lebih bisa bersikap dewasa dalam berpikir dan bertindak. Siswa mampu mengendalikan perasaan dan tidak mementingkan kepentingan ego masing-masing sehingga akan tercipta lingkungan sekolah yang baik, disiplin, aman, berprestasi dengan memiliki kematangan emosi yang stabil siswa mampu melakukan kontrol terhadap emosinya dalam menghadapi situasi yang ada.

Hasil penelitian (Astuti 2012) juga mengindikasikan berbagai permasalahan emosional remaja disebabkan oleh dampak kasus-kasus keluarga atau lingkungan 
sekitar remaja, diantaranya, korban perceraian orang tua, ketidakharmonisan antara anggota keluarga, dan sebagainya. Permasalahan emosional remaja yang muncul ialah perilaku-perilaku agresif, impulsif, mengalami gangguan perhatian seperti kurang konsentrasi, kecemasan, kehilangan harapan-harapan, dan hal-hal yang terkait dengan mood management

Fenomena yang terjadi sekarang banyak di temui masalah remaja yang berhubungan dengan kematangan emosinya, salah satunya penelitian menurut Asih dan Pratiwi (2010) yang berjudul "Perilaku Prososial Ditinjau Dari Empati dan Kematangan Emosi" pada penelitian ini di jelaskan bahwa ada hubungan positif dan signifikan antara kematangan emosi dengan perilaku prososial dan ada hubungan positif antara empati dengan perilaku prososial, seperti perilaku yang menguntungkan orang lain yang dilakukan secara sukarela dan tanpa keuntungan yang nyata bagi orang yang memberikan bantuan. Individu yang telah mencapai kematangan emosi dapat diidentifikasikan sebagai individu yang dapat menilai situasi secara kritis terlebih dahulu sebelum bertindak, tidak lagi bereaksi tanpa berpikir sebelumnya seperti anak-anak atau orang yang tidak matang emosinya, memiliki kontrol diri yang kurang baik, tidak dapat menilai situasi secara kritis terlebih dahulu sebelum bertindak dan tidak lagi bereaksi tanpa berpikir sebelumnya. Individu yang sudah memilki kematangan emosi mampu mengekspresikan emosinya dengan tepat atau sesuai dengan keadaan yang dihadapinya sehingga lebih mampu beradaptasi karena dapat menerima beragam orang dan situasi dan memberikan reaksi yang tepat sesuai dengan tuntutan yang dihadapi (Hurlock, 2004).

Kematangan emosi adalah kemampuan menerima hal-hal negatif dari lingkungan tanpa membalasnya dengan sikap yang negatif, melainkan dengan kebijakan (Martin, 2003). Menurut
Kusumawanta (2009) mengatakan bahwa kematangan emosi adalah kemampuan seseorang dalam mengontrol dan mengendalikan emosinya. Seseorang yang memiliki kematangan emosi yang sudah matang tidak cepat terpengaruh oleh rangsangan atau stimulus baik dari dalam maupun dari luar. Emosi yang sudah matang selalu belajar menerima kritik, mampu menangguhkan respon-responnya, dan memilki saluran sosial bagi energi emosinya, misalnya bermain, melakukan hobi dan sebagainya. Salah satu faktor yang mempengaruhi perkembangan kematangan emosi seseorang adalah pola asuh orang tua. Pola asuh orang tua terhadap anak bervariasi. Ada yang yang bersifat otoriter, acuh tak acuh (permisif), dan demokratis (Astuti, 2012).

\section{Analisa Bivariat}

Tabel 3. Hubungan Pola Asuh Orang Tua dengan Kematangan Emosi Remaja Di SMA N 1 Sinonsayang.

\begin{tabular}{|c|c|c|c|c|c|c|}
\hline \multirow{3}{*}{$\begin{array}{l}\text { Pola } \\
\text { asuh }\end{array}$} & \multicolumn{4}{|c|}{ Kematangan emosi } & \multirow{3}{*}{ Total } & $\begin{array}{c}\mathrm{P}- \\
\text { value }\end{array}$ \\
\hline & \multicolumn{2}{|c|}{ Terkontrol } & \multicolumn{2}{|c|}{$\begin{array}{c}\text { Tidak } \\
\text { terkontrol }\end{array}$} & & \\
\hline & $\mathrm{n}$ & $\%$ & $\mathrm{n}$ & $\%$ & & \\
\hline Baik & 31 & $62,0 \%$ & 19 & $38,0 \%$ & 50 & 0,018 \\
\hline $\begin{array}{c}\text { Kurang } \\
\text { baik }\end{array}$ & 16 & $35,6 \%$ & 29 & $64,4 \%$ & 45 & \\
\hline Total & 47 & 100 & 48 & 100 & & \\
\hline
\end{tabular}

Sumber: Data Primer 2019

Hasil penelitian ini didapatkan bahwa dari 95 responden diketahui kebanyakan responden sudah mendapatkan pola asuh yang baik yaitu sebanyak $50(52,6)$ dan mendapatkan pola asuh yang kurang baik yaitu sebanyak 45 responden $(47,4)$. Analisis hasil uji hipotesis dari pola asuh orang tua dengan kematangan emosi remaja di SMA N 1 Sinonsayang menggunakan uji statistik chi-square pada tingkat kemaknaan 95\% $(\alpha=0,05)$, dari hasil penelitian yang telah dilakukan 
menunjukkan adanya hubungan antara pola asuh orang tua dengan kematangan emosi remaja di SMA $N 1$ Sinonsayang, dimana nilai $\mathrm{P}=0,018<\alpha=0,05$. Remaja yang sudah memilki kematangan emosi, dia akan mampu untuk berperilaku sesuai dengan karakteristik kematangan emosi tersebut. Remaja yang belum memiliki kematangan emosi akan cenderung melakukan perilaku yang tidak sesuai dengan karakteristik dari kematangan emosi itu sendiri. Intinya remaja yang telah memilki kematangan emosi akan mampu melakukan kontrol terhadap emosinya. Anak usia remaja, status remaja mendorong mereka menuntut diperlakukan sebagai orang dewasa dan berupaya melepaskan diri dari ikatan emosional dengan orang tua. Tuntutan ini merupakan dilema bagi kebanyakan orang tua, sehingga orang tua perlu tepat dalam memilih cara mengasuh anak-anak remaja dengan baik.

Hasil Penelitian ini sejalan dengan penelitian yang dilakukan oleh Yuni (2018) yang mengatakan bahwa terdapat hubungan yang signifikan antara kematangan emosi remaja di Desa Kumbang Padang Permata Kabupaten Banyuasin, dimana pola asuh yang paling banyak diterapkan pada remaja dalam mengontrol kematangan emosinya adalah pola asuh demokratis. Sejalan dengan penelitian Ferieska (2016) terdapat hubungan yang signifikan antara pola asuh orang tua dengan kematangan emosi remaja. Pola asuh orangtua yang baik akan berdampak kepada kematangan emosi remaja, hal ini dikarenakan remaja yang diasuh dengan pola asuh yang baik akan memiliki kemampuan untuk dapat menghindari permusuhan karena pola asuh orangtua yang selalu menjelaskan mengenai dampak perbuatan baik dan buruk kepada dirinya, serta remaja mampu berfikir positif mengenai diri pribadinya.

Faktor-faktor yang mempengaruhi pola asuh orang tua dalam kematangan emosi yaitu: faktor lingkungan keluarga, kematangan emosi dapat berkembang dengan baik dalam lingkungan keluarga yang baik dan sehat, yaitu anggota keluarga hidup selaras satu sama lain. Hubungan yang sangat hangat dan terbuka antara orang tua dan anak-anak akan memudahkan komunikasi antara kedua bela pihak, sehingga kedua pihak bisa berkomunikasi dengan baik dan orangtua dapat mengontrol kematangan emosi anakanak. Sejalan dengan pendapat Desmita (2011) bahwa munculnya emosi seseorang sangat tergantung atau dipengaruhi lingkungan, pengalaman, dan kebudayaan. Perkembangan emosional individu merupakan perkembangan yang paling sulit untuk diklasifikasikan, hal ini ditunjukkan pada gejala kehidupan seharihari bahwa tidak jarang orang dewasa juga mengalami kesulitan untuk menyatakan perasaannya. Artinya tidak hanya jenis pola asuh orangtua dan jenis kelamin saja yang menjadi faktor tercapainya kematangan emosi usia remaja, tetapi masih ada faktor lainnya seperti lingkungan teman sebaya, pengalaman, pengaruh dunia luar dan kebudayaan.

Faktor yang mempengaruhi kematangan emosi yang pertama yaitu, rangsangan yang menimbulkan emosi, emosi akan berlangsung terus selama stimulasinya ada dan yang menyertainya masih aktif, karena emosi mempengaruhi tingkah laku, tingkah lakunya akan terus terpengaruh selama stimulasinya aktif, namun demikian emosi bukan salah satunya faktor yang menentukan tingkah laku. Kemudian faktor yang kedua yaitu, perubahan fisik dan psikologis, dapat dipengaruhi oleh rangsangan yang menimbulkan emosi. Emosi ini akan menghasilkan berbagai perubahan yang mendalam (visceral changes) dan akan mempengaruhi urat-urat kerangka dalam tubuhnya (Djaali 2008). Anak tumbuh dan berkembang di bawah asuhan orang tua, melalui orang tua, anak beradaptasi dengan lingkungannya dan mengenal dunia sekitarnya serta pola pergaulan hidup yang berlaku di lingkungannya. Ini disebabkan karena orang tua merupakan dasar pertama 
bagi pembentukan pribadi anak. Pola asuh orang tua sangat erat hubungannya dengan kepribadian anak setelah dia menjadi dewasa. Orang tua diharapkan dapat menerapkan pola asuh yang bijaksana atau menerapkan pola asuh yang sebaiknya tidak membawa kehancuran atau merusak jiwa dan watak seorang anak (Anggreni \& Notobroto, 2017).

Pemberian pola asuh orang tua kepada anak seharusnya diberikan sejak dini ketika emosi anak mulai terbentuk karena sudah tugas orang tua melengkapi dan mempersiapkan anak menuju ke kedewasaan dengan memberikan bimbingan dan pengarahan yang dapat membantu anak dalam menjalani kehidupan karena dapat dilihat pada masa usia dewasa awal tidak sedikit diantara anak yang kurang mampu mencapai kematangan dalam emosinya. Hal ini disebabkan karena banyaknya masalah yang dihadapinya dan tidak mampu mengatasinya. Induvidu yang stabil emosinya atau matang dalam emosi akan memiliki muatan emosi yang rendah, mampu menanggulangi permasalahan yang dihadapi dan tidak mengalami kesulitan emosi yang berlebih.

Hasil penelitian ini dapat disimpulkan dimana orang tua lebih lagi dalam mengawasi pergaulan anak dan menerapakan pola asuh orang tua yang baik dan sesuai dengan anak-anak remaja karena pola asuh sangat berpengaruh pada kematangan emosi remaja. Jika pola asuh yang diterapkan orang tua baik, maka kematangan emosi remaja baik namun jika penerapan pola asuh yang kurang tepat untuk anak usia remaja maka mereka cenderung melakukan hal-hal yang mengarah ke perilaku negatif. Penelitian ini didukung oleh penelitian yang dilakukan Aditya Pranata Kusuma (2009) terdapat hubungan yang signifikan dan positif antara pola asuh demokratis dengan kematangan emosi. Namun hal ini tidak sejalan dengan penelitian Jayanti (2012) menunjukkan bahwa tidak ada hubungan yang signifikan antara pola asuh orang tua dengan kematangan emosi remaja pada siswa SMA Theresiana Salatiga.

\section{SIMPULAN}

Sebagian besar responden sudah mendapatkan pola asuh yang baik. Sebagian dari siswa SMA N 1 Sinonsayang sudah memilki kematangan emosi yang baik, dan terahkir adanya hubungan antara pola asuh orang tua dengan kematangan emosi remaja di SMA N 1 Sinonsayang.

\section{DAFTAR PUSTAKA}

Ali, M \& Asrori, M. (2010). Psikologi Remaja, Perkembangan Peserta Didik. Jakarta: Bumi Aksara

Anggreni, D. \& Notobroto, B. (2017). Hubungan Pola Pengasuhan Orang Tua Dengan Tindakan Pencegahan Kekerasan Seksual Pada Anak (Studi Kasus Dalam Rangka Pencegahan Kekerasan Seksual Pada Anak Di Kota Mojokerto) Dhonna, 9(1), 9-17.

Astuti, Indri. (2012). Hubungan Konsep Diri dengan Kematangan Emosi Remaja di Dukuh Jetis, Kunden, Karanganom, Klaten. Skripsi. Fakultas Ushuluddin dan Dakwah Institut Agama Islam Negeri Surakarta

Asih, G. Y \& Pratiwi, M. M. S. (2010). Perilaku Prososial Ditinjau dari Empati dan Kematangan Emosi. Jurnal Psikologi Vol 1, No 1.

Baumrind, (2012). Jenis Pola Asuh Anak. Jakarta: Galia Indonesia.

Djaali. 2008. Psikologi Pendidikan. Jakarta: Bumi Aksara

Devi. (2012). Hubungan Pola Asuh Orang Tua Dengan Kecerdasan Sosial Pada Siswa Kelas IV SD Jatimulyo 01.SKRIPSI. 
Desmita. (2011). Psikologi Perkembangan Peserta Didik. Bandung. PT. Remaja Rosdakarya.

Ferieska. F \& Yuliana, I.L(2016). Hubungan Pola Asuh Orang Tua Dengan Kematangan Emosi Remaja. Jurnal Psikologi Vol 12, No 2.

Hurlock, Elizabeth B. (2004). Developmenral Psychology. Jakarta: Erlangga

Jayanti, R. D.(2012). Hubungan Pola Asuh Orang Tua Dengan Kematangan Emosi Pada Siswa SMA Theresiana Salatiga. Skripsi. Fakultas Keguruan Dan Ilmu Pendidikan Universitas Kristen Satya Wacana Salatiga.

Kapri, U. C. Rani, N. (2014). Emotional Maturity: Characteristics And Levels. International Journal Of Technological Exploration And Leasrning. 3. 1. 359- 361

Kementerian Kesehatan RI. Pusat Data dan Informasi. (2014). t.t Situasi Kesehatan Reproduksi Remaja. Jakarta Selatan.

Kusumawanta, D.G.B. (2009). Imam diamang batas. Yogykarta: Kanisius.

Kusuma, A. (2009). Hubungan Pola Asuh Orang Tua Dengan Kematangan Emosi Siswa Kelas XI Sma Negeri Bergas. Skripsi. Semarang: Program Studi Bimbingan Dan Konseling. Fakultas Ilmu Pendidikan. Universitas Negeri Semarang.

Martin, Anthony. 2003. Emotional Quality Management, Refleksi, Revisi, dan Revitalisasi Hidup Melalui Kekuatan Emosi. Jakarta: Arga
Notoatmodjo. (2012). Metodelogi Penelitian Kesehatan. Jakarta: Rinela Cipta.

Setiadi (2013).Konsep Dan Praktek Penulisan Riset Keperawatan (Edisi 2). Yogyakarta: Graha Ilmu

Wong, D.L. (2009). Buku Ajar Keperawatan Pediatric. Edisi 6. Volume 1.

Jakarta a: EGC

Yahya. N. (2010). Hubungan pola asuh orangtua terhadap kematangan emosi remaja di kampung bontoa kelurahan parang loe kecamatan tamalanrea makassar. Hubungan Pola Asuh Orangtua Terhadap Kematangan Emosi Remaja Di Kampung Bontoa Kelurahan Parang Loe Kecamatan Tamalanrea Makassar.

Yuni, S. (2018). Hubungan Pola Asuh Orang Tua Dengan Kematangan Emosi Remaja Di Desa Kumbang Padang Permata Kecamatan Banyuasin.SKRIPSI. 